\title{
SELULOSA DARI AMPAS TEBU SEBAGAI ADSORBEN PADA MINYAK BEKAS PENGGORENGAN
}

\author{
[Quality improvement of Used Cooking Oil by Using Sugarcane Bagasse as \\ Adsorbent]
}

\author{
Winda Trisna Wulandari ${ }^{{ }^{*}}$, Rosmaya Dewi ${ }^{1}$ \\ 1) Prodi Farmasi, STIKes Bakti Tunas Husada Tasikmalaya, Indonesia \\ *)Coresponding author: windatrisna@stikes-bth.ac.id
}

Diterima 17 September 2018, Disetujui 9 Desember 2018

\begin{abstract}
Frying can cause oxidation of fatty acids content of oil that produce harmful compounds including peroxides, aldehydes and acrylamides. One way that can be used to eliminate these dangerous compounds is by using adsorbents. Recently, adsorbents from natural fibers have been developed. One of them is cellulose, which contains $40-50 \%$ in bagasse. Therefore, this study aims to utilize cellulose from bagasse as an adsorbent in used cooking oil. Cellulose extraction from bagasse was carried out by adding $250 \mathrm{~mL}$ of $0.735 \% \mathrm{NaOCl}$ and $150 \mathrm{~mL}$ of $17.5 \% \mathrm{NaOH}$. Adsorbent testing was carriet out with an addition of cellulose to used cooking oil for $1 \times 24$ hours and $2 \times 24$ hours, following with measurement of the quality of used cooking oil.. The test results showed that immersion of cellulose in used cooking oil for $2 \times 24$ hours reduced both acid numbers to $52.31 \%$ and peroxide number to $68.36 \%$, but the water content value increased by $45.29 \%$. Based on this research, it can be concluded that cellulose from sugarcane bagasse has the potential as an adsorbent in used cooking oil.
\end{abstract}

Keyword: cellulose, sugarcane bagasse, adsorbent, used cooking oil

\begin{abstract}
ABSTRAK
Penggorengan minyak dapat menyebabkan asam lemak yang terdapat di dalamnya mengalami oksidasi menghasilkan senyawa yang berbahaya bagi kesehatan, diantaranya adalah senyawa peroksida, aldehid dan akrilamid. Salah satu cara yang dapat digunakan untuk menghilangkan senyawa-senyawa berbahaya tersebut adalah dengan cara penggunaan adsorben. Akhir-akhir ini banyak dikembangkan adsorben yang berasal dari serat alami. Salah satunya adalah selulosa yang terkandung $40-50 \%$ dalam ampas tebu. Oleh karena itu, penelitian ini bertujuan untuk memanfaatkan selulosa dari ampas tebu sebagai adsorben pada minyak bekas penggorengan. Ekstraksi selulosa dari ampas tebu dilakukan dengan cara menambahkan $250 \mathrm{~mL}$ larutan $\mathrm{NaOCl} 0,735 \%$ dan $150 \mathrm{~mL}$ larutan $\mathrm{NaOH} 17,5 \%$. Pengujian adsorben dilakukan dengan cara menambahkan selulosa ke dalam minyak bekas penggorengan selama 1×24 jam dan 2x24 jam. Kemudian dilakukan pengukuran kualitas minyak goreng. Hasil pengujian menunjukkan bahwa perendaman minyak jelantah dengan menggunakan selulosa selama 2x24 jam dapat menurunkan bilangan asam sampai dengan $52,31 \%$ dan menurunkan bilangan peroksida mencapai $68,36 \%$, akan tetapi nilai kadar airnya meningkat sebesar $45,29 \%$. Berdasarkan penelitian yang telah dilakukan, dapat disimpulkan bahwa selulosa dari ampas tebu berpotensi sebagai adsorben pada minyak bekas penggorengan.
\end{abstract}

Kata kunci: selulosa, ampas tebu, adsorben, minyak jelantah. 


\section{LATAR BELAKANG}

Penggunaan minyak goreng di masyarakat sudah semakin meningkat. Selain digunakan sebagai media penggorengan, minyak goreng juga diyakini masyarakat dapat membuat makanan menjadi lebih gurih dan nikmat. Tingginya harga minyak goreng di pasaran membuat masyarakat terutama pedagang makanan menggunakan minyak goreng bekas atau yang disebut dengan minyak jelantah sebagai media penggorengan.

Hasil penelitian Suroso (2013) menyebutkan bahwa minyak goreng habis pakai tidak memenuhi syarat Standar Nasional Indonesia (SNI) ditinjau dari bilangan peroksida, bilangan asam dan kadar airnya. Selain itu, penggunaan minyak jelantah juga ternyata menimbulkan berbagai permasalahan terutama di bidang kesehatan. Pemanasan minyak goreng pada suhu tinggi dapat menyebabkan terjadinya proses polimerisasi, hidrolisis dan oksidasi yang dapat menghasilkan senyawa alkohol, aldehid, hidrokarbon aromatik dan akrolin yang bersifat toksik. Senyawasenyawa yang dihasilkan tersebut dapat menyebabkan terjadinya peningkatan peroksida intraseluler, kerusakan DNA, penyebaran sel yang cepat dan pelepasan sitokin proinflamatori yang berhubungan dengan kenaikan genotoksisitas dan tumor. (Yu Peng et al, 2016)

Hasil penelitian dari Oeij et al (2007) menyebutkan bahwa pemberian minyak jelantah kepada mencit menimbulkan kerusakan hati dan menginisiasi respon peradangan hati. Hal ini diduga karena adanya reaksi radikal bebas yang berkelanjutan dengan adanya peroksidasi lipid serta terbentuknya senyawa monoaldehid yang merupakan produk sekunder peroksidasi.

Beberapa penelitian telah dilakukan untuk mengatasi permasalahan tersebut diantaranya adalah penggunaan daun zaitun dan ekstrak teh sebagai antioksidan pada minyak kedelai hasil pemanasan dengan menggunakan microwave (Malheiro et al, 2013). Namun aktivitas antioksidan akan menurun apabila penggorengan dilakukan pada suhu tinggi (Min dan Choe, 2007). Metode fisika dan kimia lain yang paling disarankan pada proses pemurnian minyak jelantah adalah penggunaan adsorben (Bonassa et al, 2016). Akhirakhir ini adsorben yang berasal dari serat alami sedang banyak dikembangkan. Selain karena ketersediaannya yang melimpah dan harganya yang relatif murah, adsorben dari serat alami juga memiliki sifat biodegradabel atau mudah terdegradasi secara alamiah sehingga diharapkan limbah yang dihasilkan tidak berbahaya bagi masyarakat dan lingkungan di sekitarnya (Olivera et al, 2016). Salah satu serat alami yang banyak ditemukan adalah selulosa. Selulosa dapat dengan mudah ditemukan pada semua tumbuhan, salah satunya dapat diperoleh dari ampas tebu yang 
memiliki kandungan selulosa mencapai 40-50 \%, hemiselulosa $23-35 \%$ dan lignin sebesar 18-24 \% (Mandal dan Chakrabarty, 2011).

Sampai saat ini penggunaan selulosa sebagai adsorben untuk minyak bekas penggorengan atau yang disebut dengan minyak jelantah masih belum dikembangkan padahal ampas tebu sendiri berpotensi digunakan sebagai adsorben seperti pada penelitian Ramdja et al (2010) yang menemukan bahwa ampas tebu dapat menurunkan kadar air sebesar 0,0050\% dan perendaman ampas tebu selama $2 \times 24$ jam dapat mengadsorbsi asam lemak bebas sebesar 0,0999\%. Oleh karena itu, penelitian ini bertujuan untuk memanfaatkan selulosa dari ampas tebu sebagai adsorben pada minyak jelantah dengan harapan hasilnya lebih baik dibandingkan dengan ampas tebunya.

\section{METODE PENELITIAN}

\section{Bahan dan Peralatan}

Bahan-bahan yang digunakan dalam penelitian ini adalah ampas tebu, minyak kelapa sawit bekas penggorengan yang diperoleh dari pedagang makanan di daerah Tasikmalaya, $\mathrm{NaOCl}, \mathrm{NaOH}$, $\mathrm{H}_{2} \mathrm{SO}_{4}$, tanah diatom, etanol, phenolfthalein, $\mathrm{KOH}$, asam asetat glasial, isooktan, $\mathrm{KI}, \mathrm{Na}_{2} \mathrm{~S}_{2} \mathrm{O}_{3}, \mathrm{KIO}_{3}, \mathrm{HCl}$, larutan kanji, $\mathrm{K}_{2} \mathrm{Cr}_{2} \mathrm{O}_{7}$.

Peralatan yang digunakan dalam penelitian ini anatra lain adalah peralatan gelas laboratorium, magnetic stirrer, ayakan, stopwatch, neraca analitik, oven, desikator, cawan porselen dan spektrometer FTIR (Simadzu).

\section{Prosedur Penelitian}

\section{Penyiapan Ampas Tebu}

Ampas tebu diambil dari limbah pedagang air tebu di daerah Tasikmalaya, Jawa Barat. Kemudian ampas tebu dikeringkan di bawah sinar matahari, setelah itu digiling sehingga diperoleh sampel berbentuk serbuk halus.

\section{Ekstraksi Selulosa}

Penghilangan lignin (delignifikasi) dilakukan dengan cara menambahkan $250 \mathrm{~mL}$ larutan $\mathrm{NaOCl}$ 0,735 \% ke dalam 15 gram ampas tebu dalam labu dasar bulat. Campuran tersebut direfluks selama 6 jam dengan pengadukan konstan 350 rpm pada suhu sekitar $45^{\circ} \mathrm{C}$. Hasil refluks disaring dengan alat penyaring vacum dan dibilas dengan aqua $\mathrm{dm}$ sampai $\mathrm{pH}$ nya netral. Residu hasil proses sebelumnya dicampurkan dengan $150 \mathrm{~mL}$ larutan $\mathrm{NaOH} 17,5 \%$ dan direfluks selama 3 jam dengan pengadukan konstan $350 \mathrm{rpm}$ pada suhu sekitar $45{ }^{\circ} \mathrm{C}$ untuk menghilangkan hemiselulosa. Campuran hasil refluks disaring dan dibilas dengan aqua dm sampai netral. Residu yang diperoleh dikeringkan di udara terbuka.(Wulandari et al, 2016)

\section{Penggunaan Selulosa sebagai Adsorben pada MInyak Bekas Penggorengan}

Minyak kelapa sawit bekas penggorengan disiapkan masing-masing 
sebanyak $100 \mathrm{~mL}$. Kemudian selulosa hasil ekstraksi dari ampas tebu dimasukkan ke dalam minyak tersebut dan direndam dengan variasi waktu 1×24 jam dan 2x24 jam. Filtrat dari hasil penyaringan dianalisis kualitasnya mengikuti Badan Standarisasi Nasional, 2012 dan Badan Standarisasi Nasional, 2013.

\section{Penentuan Kualitas Minyak Goreng}

\section{a. Pengujian Kadar Air dan Bahan Menguap}

Kadar air dan bahan menguap dihitung berdasarkan bobot yang hilang selama pemanasan dalam oven pada suhu $(130 \pm 1){ }^{\circ} \mathrm{C}$. Pengujian dilakukan dengan mengacu pada Standar Nasional Indonesia (SNI) nomor SNI 7709:2012 dan SNI 3741:2013. Cawan porselen dan tutupnya dipanaskan dalam oven suhu $(130 \pm 1)^{\circ} \mathrm{C}$ selama kurang lebih 30 menit dan didinginkan dalam desikator selama 20-30 menit, kemudian ditimbang dengan neraca analitik $\left(\mathrm{W}_{0}\right)$. Setelah itu, $2 \mathrm{~g}$ sampel dimasukan ke dalam cawan, ditutup dan ditimbang $\left(\mathrm{W}_{1}\right)$. Cawan yang berisi sampel dipanaskan dalam keadaan terbuka dengan meletakkan tutup pinggan disamping pinggan di dalam oven pada suhu $(130 \pm 1){ }^{\circ} \mathrm{C}$ selama 30 menit setelah suhu oven $(130 \pm 1){ }^{\circ} \mathrm{C}$. Setelah selesai, cawan ditutup ketika masih di dalam oven dan dipindahkan segera ke dalam desikator dan didinginkan selama 20-30 menit hingga suhunya sama dengan suhu ruang kemudian ditimbang $\left(\mathrm{W}_{2}\right)$.
Pengerjaan dilakukan hingga diperoleh bobot tetap. Kisaran hasil 2 kali pengulangan maksimal $10 \%$ dari nilai rata-rata kadar air dan bahan menguap. Kadar air dan bahan menguap dalam contoh dihitung sebagai berikut:

$$
\begin{aligned}
& \text { Kadar air dan bahan menguap }(\%)= \\
& \frac{W_{1}-W_{2}}{W_{1}-W_{0}} \times 100 \ldots \ldots \ldots \ldots \ldots \ldots \ldots \ldots . \ldots \ldots \ldots . \ldots . \ldots . \ldots
\end{aligned}
$$

Keterangan:

$\mathrm{W}_{0}$ : bobot pinggan kosong dan tutupnya, dinyatakan dalam gram $(\mathrm{g})$;

$\mathrm{W}_{1}$ : bobot pinggan, tutupnya dan contoh sebelum dikeringkan, dinyatakan dalam gram $(\mathrm{g})$;

$\mathrm{W}_{2}$ : bobot pinggan, tutupnya dan contoh setelah dikeringkan, dinyatakan dalam gram $(\mathrm{g})$.

\section{b. Pengujian Asam Lemak Bebas/ Bilangan Asam}

Pengujian asam lemak bebas/ bilangan asam mengacu pada SNI 7709:2012 untuk minyak goreng sawit dan SNI 3741:2013 untuk minyak goreng selain minyak goreng sawit. Sebanyak 10$50 \mathrm{~g}$ sampel (W) dimasukan ke dalam Erlenmeyer dan dilarutkan dengan $50 \mathrm{~mL}$ etanol hangat serta ditambahkan 5 tetes larutan fenolftalein sebagai indikator. Kemudian larutan dititrasi dengan $\mathrm{KOH}$ atau $\mathrm{NaOH}$ 0,1 N sampai terbentuk warna merah muda yang bertahan selama 30 detik, kemudian catat volume larutan $\mathrm{NOH}$ atau $\mathrm{NaOH}$ yang diperlukan (V). Kisaran hasil 2 kali ulangan maksimal 10\% dari nilai rata-rata hasil asam lemak bebas (sebagai asam palmitat). Berdasarkan SNI 7709:2012 untuk minyak goreng sawit, asam lemak bebas/bilangan asam 
dihitung sebagai asam palmitat dengan perhitungan sebagai berikut:

$$
\mathrm{ALB}=\frac{25,6 \times \mathrm{V} \times \mathrm{N}}{\mathrm{W}}
$$

Keterangan:

ALB : Asam lemak bebas sebagai palmitat

$\mathrm{V}$ : volume larutan $\mathrm{KOH}$ atau $\mathrm{NaOH}$ yang diperlukan, dalam $\mathrm{mL}$.

$\mathrm{N}$ : normalitas larutan $\mathrm{KOH}$ atau $\mathrm{NaOH}$, dalam normalitas $(\mathrm{N})$.

W : bobot contoh uji, dalam gram (g).

\section{c. Pengujian Bilangan Peroksida}

Pengujian bilangan peroksida mengacu pada SNI 7709:2012 dan SNI $3741: 2013$. Sebanyak $(5 \pm 0,05) \mathrm{g}$ sampel (W) ditimbang, kemudian dimasukan ke dalam erlenmeyer kering. Selanjutnya ditambahkan $50 \mathrm{~mL}$ larutan asam asetat glasial-isooktan (3:2). Erlenmeyer ditutup dan diaduk hingga larutan homogen. Setelah itu, ke dalam Erlenmeyer ditambahkan 0,5 mL larutan kalium iodida jenuh dengan menggunakan pipet ukur dan dikocok selama 1 menit. Selanjutnya ditambahkan $30 \mathrm{~mL}$ air suling dan erlenmeyer ditutup dengan segera. Kemudian larutan dikocok dan dititrasi dengan $\mathrm{Na}_{2} \mathrm{~S}_{2} \mathrm{O}_{3} 0,1 \mathrm{~N}$ hingga warna kuning hampir hilang dan selanjutnya ditambahkan indikator kanji $0,5 \mathrm{~mL}$ serta titrasi dilanjutkan. Larutan harus dikocok kuat untuk melepaskan semua iod dari lapisan pelarut hingga warna biru hilang. Pengujian ini dilakukan secara duplo dan dilakukan penetapan blanko. Perhitungan bilangan peroksida dinyatakan sebagai miliekivalen $\mathrm{O}_{2}$ per $\mathrm{Kg}$ lemak dengan rumus berikut:
Bilangan peroksida $\left(\right.$ mek $\left.\mathrm{O}_{2} / \mathrm{Kg}\right)=$

$\frac{1000 \times \mathrm{nN} \times\left(\mathrm{V}_{0}-\mathrm{V}_{1}\right)}{\mathrm{W}}$

Keterangan:

$\mathrm{N}$ : normalitas larutan standar $\mathrm{Na}_{2} \mathrm{~S}_{2} \mathrm{O}_{3} \quad 0,01$ $\mathrm{N}$, dalam normalitas, $(\mathrm{N})$;

$\mathrm{V}_{\mathrm{o}}$ : volume larutan $\mathrm{Na}_{2} \mathrm{~S}_{2} \mathrm{O}_{3} \quad 0,1 \mathrm{~N}$ yang diperlukan pada penitaran contoh, dalam mililiter $(\mathrm{mL})$;

$\mathrm{V}_{1}$ : volume larutan $\mathrm{Na}_{2} \mathrm{~S}_{2} \mathrm{O}_{3} \quad 0,1 \mathrm{~N}$ yang diperlukan pada penitaran blanko, dalam mililiter $(\mathrm{mL})$;

W : bobot contoh, dinyatakan dalam gram (g).

\section{Analisis Gugus Fungsi}

Analisis gugus fungsi untuk ampas tebu dan selulosa menggunakan alat Spektroskopi Infra Merah Shimadzu Prestige 21. Preparasi sampel untuk selulosa dan nanoselulosa adalah dengan mencampurkan sejumlah kecil sampel dengan $\mathrm{KBr}$ kemudian dibuat menjadi pelet dan discan pada bilangan gelombang dari $4000-500 \mathrm{~cm}^{-1}$

\section{HASIL DAN PEMBAHASAN}

\section{Selulosa dari Ampas Tebu}

Isolasi selulosa terdiri dari dua tahap yaitu proses delignifikasi (penghilangan lignin) dan penghilangan hemiselulosa. Untuk mengetahui apakah lignin dan hemiselulosa sudah berhasilkan dihilangkan adalah dengan melakukan pengujian dengan menggunakan FTIR. Hasil dari pengukuran FTIR untuk ampas tebu dan selulosa ditunjukkan pada Gambar 1. 


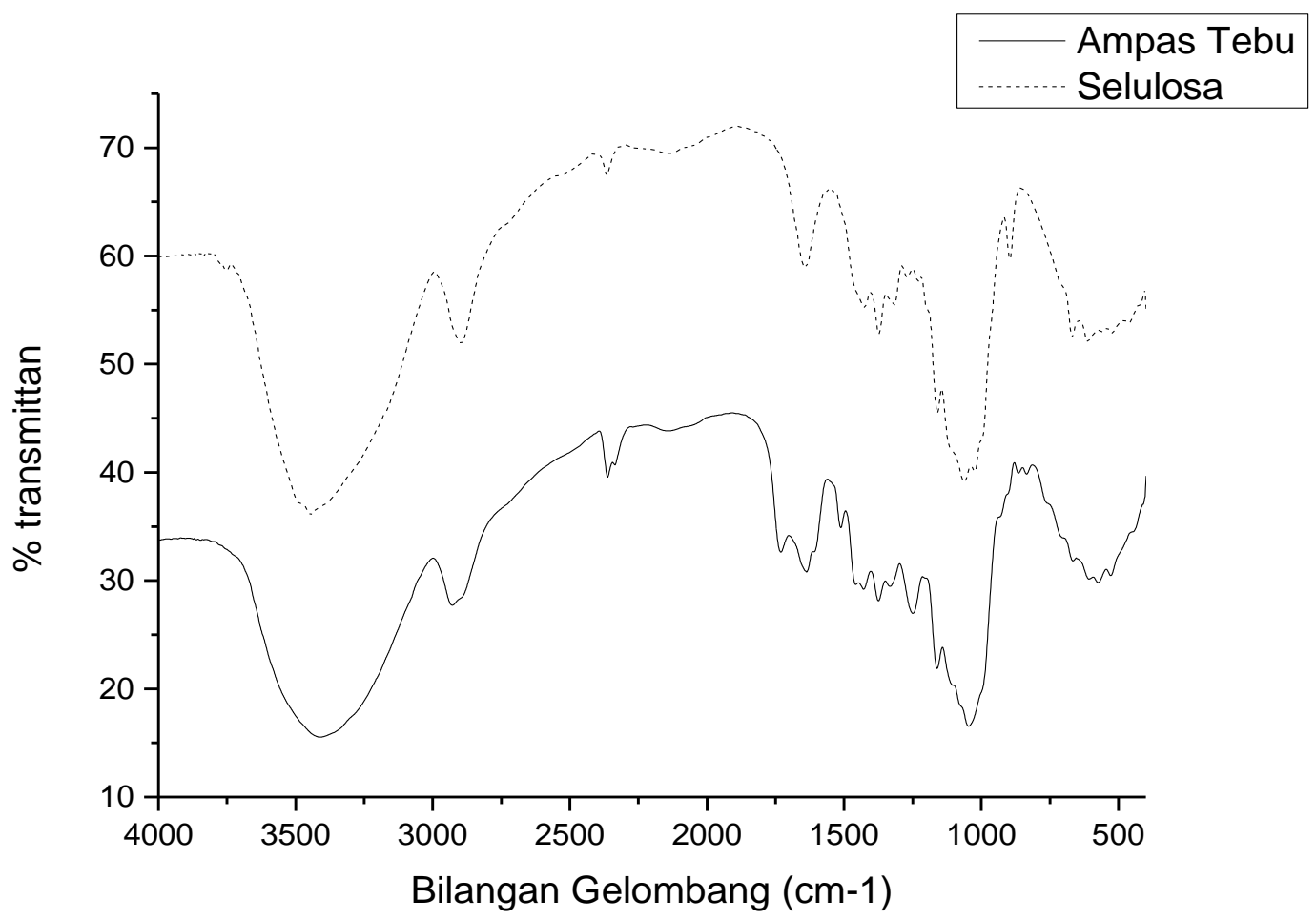

Gambar 1. Grafik FTIR Ampas Tebu dan Selulosa

Berdasarkan Gambar 1 dapat dilihat bahwa ada 3 peak yang terdapat pada ampas tebu tetapi tidak terdapat pada selulosa, yaitu pada bilangan gelombang $1249,80 \mathrm{~cm}^{-1}$ yang menunjukkan adanya vibrasi C-O untuk aryl grup pada lignin, bilangan gelombang 1512,37 $\mathrm{cm}^{-1}$ menunjukkan adanya $\mathrm{C}=\mathrm{C}$ cincin aromatik yang terdapat pada lignin. Bilangan gelombang $1730,57 \mathrm{~cm}^{-1}$ menunjukkan adanya gugus karboksilat pada hemiselulosa dan lignin. Berdasarkan ketiga peak tersebut dapat disimpulkan bahwa selulosa yag dihasilkan sudah bebas dari lignin dan hemiselulosa.

Berdasarkan hasil FTIR selulosa, dapat dilihat bahwa pada bilangan gelombang $3445,15 \mathrm{~cm}^{-1}$ menunjukkan adanya vibrasi $-\mathrm{OH}$, bilangan gelombang
2897,64 menunjukkan adanya vibrasi - $\mathrm{CH}$ dan bilangan gelombang $1644,74 \mathrm{~cm}^{-1}$ menunjukkan adanya vibrasi $-\mathrm{OH}$ yang teradsorbsi oleh air.

\section{Selulosa sebagai Adsorben pada Minyak Bekas Penggorengan}

Parameter yang menunjukkan kualitas minyak bekas penggorengan pada penelitian ini diantarnya adalah kadar air, bilangan asam dan bilangan peroksida. Hasil pengujian parameter kadar air dapat dilihat pada Gambar. 2.

Berdasarkan grafik pada Gambar. 2 dapat dilihat bahwa perendaman minyak bekas penggorengan dapat menurunkan bilangan asam dan bilangan peroksida. Pada perendaman minyak goring dengan selulosa selama $2 \times 24$ jam dapat menurunkan nilai bilangan asam 
mencapai $52,31 \%$ dan menurunkan bilangan peroksida mencapai $68,36 \%$. Akan tetapi kadar airnya meningkat dari 0,0819\% menjadi $0,1497 \%$.

Hasil pengujian kualitas minyak goreng tersebut menunjukkan bahwa selulosa memiliki pori yang dapat menyerap molekul yang ukurannya besar maupun kecil. Selain itu juga selulosa

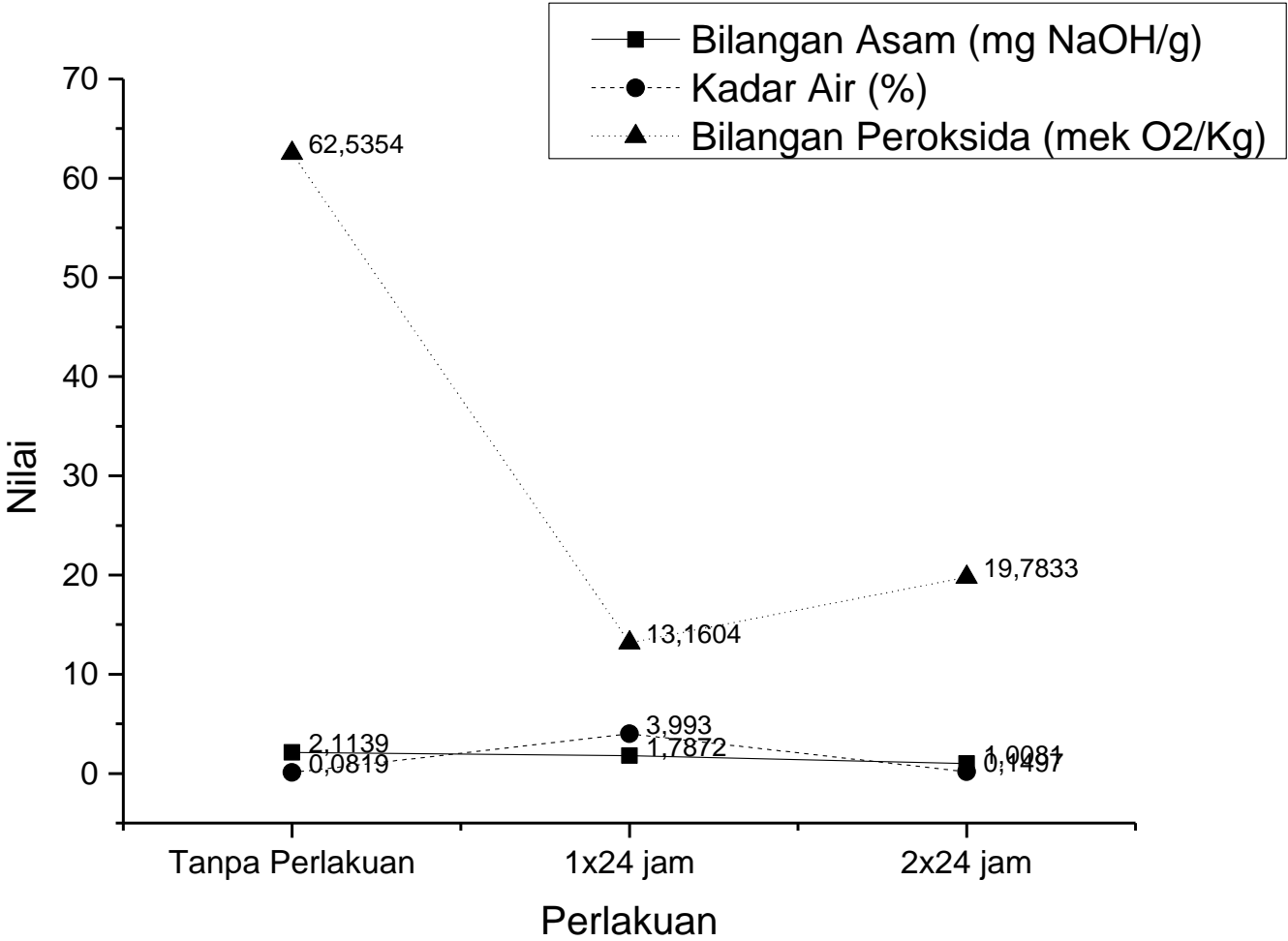

Gambar 2. Grafik Hasil Pengujian Kualitas Minyak Bekas Penggorengan

\section{KESIMPULAN}

Berdasarkan hasil penelitian dapat disimpulkan bahwa perendaman selulosa dari ampas tebu pada minyak goreng hasil penggorengan selama $2 \times 24$ jam dapat menurunkan bilangan asam mencapai $52,31 \%$ dan menurunkan bilangan peroksida mencapai 68,36\%, akan tetapi menaikkan kadar air sebesar 45,29\%. Sehingga selulosa dari ampas tebu dapat memiliki gugus fungsi $-\mathrm{OH}$ yang memungkinkan terjadinya interksi dengan asam lemak dalam hal ini asam palmitat dan peroksida. Akibat adanya proses adsorbsi tersebut maka akan mengakibatkan bilang asam dan bilangan peroksida menjadi menurun dan kualitas minyak goreng menjadi meningkat.

Perlakuan berpotensi sebagai adsorben pada minyak bekas penggorengan.

\section{UCAPAN TERIMAKASIH}

Ucapan terima kasih disampaikan secara khusus kepada DRPM Kemenristekdikti yang telah mendanai penelitian ini melalui program hibah Penelitian Dosen Pemula Tahun 2018. 


\section{DAFTAR PUSTAKA}

Badan Standardisasi Nasional, 2012, Standar Minyak Goreng Sawit, SNI 7709:2012, Jakarta: BSN.

Badan Standardisasi Nasional, 2013, Standar Minyak Nabati Selain Kelapa Sawit. SNI 3741:2013, Jakarta: BSN.

Bonassa, G., Schneider, L.T., Alves, H.J., Meier, T.R.W., Frigo, E.P., and Teleken, J.G. 2016. Sugarcane Bagasse Ash for Waste Cooking Oil Treatment Applications, Journal of Environmental Chemical Engineering, http://dx.doi.org/10/1016/j.jece.201 $\underline{6.09 .017}$

Malheiro, R., Rodrigues, N., Manzke, G., Bento, A., and Pereira, J.A. 2013. The Use of Olive Leaves and Tea Extracts as Effective Antioxidants Against The Oxidation of Soybean Oil Under Microwave Heating, Industrial Crops and Products, 44, 37-43

Mandal, A dan Chakrabarty, D. 2011. Isolation of nanocellulose from waste sugarcane bagasse (SCB) and its characterization, Carbohydrate Polymers, 86: 12911299

Min, D.B., and Choe, E. 2007. Chemistry of Deep-Fat Frying Oil: An Overview, Journal of Food Science, 72(5): R77-R86.

Ramdja, A.F., Febrina, L., and Krisdianto, D. 2010. Pemurnian Minyak Jelantah Menggunakan Ampas Tebu sebagai Adsorben, Jurnal Teknik Kimia, 17(1): 7-14

Suroso, A.S., 2013, Kualitas Minyak Goreng Habis Pakai Ditinjau dari Bilangan Peroksida, Bilangan Asam dan Kadar Air, Jurnal Kefarmasian Indonesia, 3, 2, 77-88

Oeij, A.A., Atmadja, W.L., Achmad, S., and Tohardi, A, Gambaran Anatomi Mikroskopik dan Kadar Malondialdehida pada Hati Mencit setelah Pemberian Minyak Kelapa Sawit Bekas Menggoreng, 7, 1, 15-25

Olivera, S., Muralidhara, H.B., Venkatesh, K., Guna, K., Gopalakrishna, K., Kumar, Y., 2016., Potential applications of cellulose and chitosan nanoparticles/composites in wastewater treatment: A Review, Carbohydrate Polymers

Wulandari, W.T., Rochliadi, and Arcana, I.M. 2016. Nanocellulose Prepared by Acid Hydrolysis of Isolated Cellulose from Sugarcane Bagasse, Conf. Ser.: Mater. Sci. Eng. 107, doi: 10.1088/1757899X/107/1/012045

Yu Peng, C., Hang Lan, C., Chen Lin, P., and Chun Kuo, Y. 2016. Effect of Cooking Method, Cooking Oil, and Food Type on Aldehyde Emissions in Cooking Oil Fumes, Journal of Hazardous Materials, http://dx.doi.org/10.1016/j.jhazmat. $\underline{2016.10 .045}$ 